\title{
Zona glomerulosa cells of the mouse adrenal cortex are intrinsic electrical oscillators
}

\author{
Changlong Hu, ${ }^{1,2}$ Craig G. Rusin, ${ }^{3}$ Zhiyong Tan, ${ }^{2}$ Nick A. Guagliardo, ${ }^{2}$ and Paula Q. Barrett ${ }^{2}$ \\ ${ }^{1}$ School of Life Sciences, State Key Laboratory of Medical Neurobiology and Institutes of Brain Science, Fudan University, \\ Shanghai, China. ${ }^{2}$ Department of Pharmacology, University of Virginia, Charlottesville, Virginia, USA. \\ ${ }^{3}$ Department of Pediatric Cardiology, Baylor College of Medicine, Houston, Texas, USA.
}

\begin{abstract}
Aldosterone, which plays a central role in the regulation of blood pressure, is produced by zona glomerulosa (ZG) cells of the adrenal gland. When dysregulated, aldosterone is pathogenic and contributes to the development and progression of cardiovascular and renal disease. Although sustained production of aldosterone requires persistent $\mathrm{Ca}^{2+}$ entry through low-voltage activated $\mathrm{Ca}^{2+}$ channels, isolated $\mathrm{ZG}$ cells are considered nonexcitable, with recorded membrane voltages that are too hyperpolarized to permit $\mathrm{Ca}^{2+}$ entry. Here, we show that mouse ZG cells within adrenal slices spontaneously generate membrane potential oscillations of low periodicity. This innate electrical excitability of ZG cells provides a platform for the production of a recurrent $\mathrm{Ca}^{2+}$ signal that can be controlled by Ang II and extracellular potassium, the 2 major regulators of aldosterone production. We conclude that native ZG cells are electrical oscillators, and that this behavior provides what we believe to be a new molecular explanation for the control of $\mathrm{Ca}^{2+}$ entry in these steroidogenic cells.
\end{abstract}

\section{Introduction}

Autonomous overproduction of aldosterone, termed primary hyperaldosteronism (PA), is the most common form of endocrine hypertension ( $13 \%$ incidence), but among patients with resistant hypertension, its incidence increases substantially to $20 \%(1,2)$. Aldosterone raises blood pressure and enhances renal Na reabsorption and $\mathrm{K}$ excretion. When aldosterone production is inappropriate for the level of salt, it is pathogenic, and hypertensive subjects with inappropriate levels have increased target organ damage and a greater odds ratio for cardiovascular disease than do patients with hypertension of unknown cause $(3,4)$. Because intracellular $\mathrm{Ca}^{2+}$ is the critical signal controlling aldosterone production, an understanding of the mechanisms underlying $\mathrm{Ca}^{2+}$ entry is paramount to rational drug design.

Mouse models of PA have underscored the critical importance of $\mathrm{K}^{+}$channel activity in the control of aldosterone production (5-7); indeed, genetic variation in the human KCNJ5 gene (encoding the inwardly rectifying $\mathrm{K}^{+}$channel) is found in a subset of patients with severe tumorigenic PA (8). Nevertheless, these studies have also raised fundamental questions about the physiological control of aldosterone production. How can the sustained production of aldosterone be regulated in what conventionally has been regarded as a nonexcitable cell if the membrane potential $(\mathrm{Vm})$ of the cell rests close to the equilibrium potential for $\mathrm{K}^{+}-$a voltage that is not favorable for the opening of voltage-gated $\mathrm{Ca}^{2+}$ channels and the enhanced entry of $\mathrm{Ca}^{2+}$, the critical intracellular signal $(9,10)$ ?

Whereas the initiation of aldosterone production from the adrenal zona glomerulosa $(\mathrm{ZG})$ cell requires a rise in intracellular $\mathrm{Ca}^{2+}$ that may originate from intracellular store release, the sustained production of aldosterone requires extracellular $\mathrm{Ca}^{2+}$ entry (11-14). Transmission of the $\mathrm{Ca}^{2+}$ signal from the cytosol to the mitochondria increases both the early step in aldosterone production (StAR-dependent transfer of cholesterol to the P450scc enzyme,

Conflict of interest: The authors have declared that no conflict of interest exists. Citation for this article: J Clin Invest. 2012;122(6):2046-2053. doi:10.1172/JCI61996.
CYP11A1) and the late step (governed by the transcriptional regulation of aldosterone synthase, CYP11B2) (15-17). In vivo, plasma $\mathrm{K}^{+}$and Ang II are the major regulators of aldosterone production, and for their actions, $\mathrm{Ca}^{2+}$ is an essential signal (18).

The major $\mathrm{Ca}^{2+}$-selective ion channel class identified in the plasma membrane of the $Z G$ cell is the low-voltage-activated T-type (Cav3.x) $\mathrm{Ca}^{2+}$ channel $(9,19-23)$. As a class, these channels open at low threshold (membrane voltages positive to $-70 \mathrm{mV}$ ); inactivate rapidly, yet incompletely, at negative resting membrane voltages; close slowly; and have small unitary conductances (2426). Among the 3 members of the Cav3.x family, Cav3.2 channels are the predominant subtype expressed in ZG cells (27). Because the voltage range over which Cav3.2 channels activate and inactivate overlaps, Cav3.2 channels can carry steady-state (window) currents within these voltage limits. Indeed, direct recordings of steady-state Cav3.2 currents in bovine ZG cells revealed a small steady-state open probability of less than 0.002 at membrane voltages positive to $-60 \mathrm{mV}(28)$. It has been suggested that steady-state Cav3.2 currents represent the primary component of $\mathrm{Ca}^{2+}$ entry supporting sustained steroidogenesis $(10,29,30)$. Nevertheless, whether at rest $(9,31,32)$ or during stimulation with Ang II or plasma $\mathrm{K}^{+}(10,31)$, membrane voltages recorded from dissociated cultured $Z G$ cells remain in a range $(-90$ to $-70 \mathrm{mV}$ ) at which steady-state $\mathrm{Ca}^{2+}$ entry is negligible. Here, we describe a fundamental property of the ZG cell, the innate capacity to generate a recurring electrical signal, and showed that this intrinsic oscillatory behavior enabled Cav3.2 channels to provide an amplified and graded sustained $\mathrm{Ca}^{2+}$ signal.

\section{Results}

$Z G$ cells are electrically excitable. Whole-cell current clamp recordings were made of mouse $Z G$ cells retained within an adrenal slice. The majority of $Z G$ cells had a mean resting $V m$ of $-82.2 \pm$ $0.1 \mathrm{mV}$ and exhibited spontaneous $\mathrm{Vm}$ oscillations over recording periods of 3-10 minutes (73 of 85 cells). In most cells, oscillations were continuous, rhythmic, and of low periodicity, as 
A
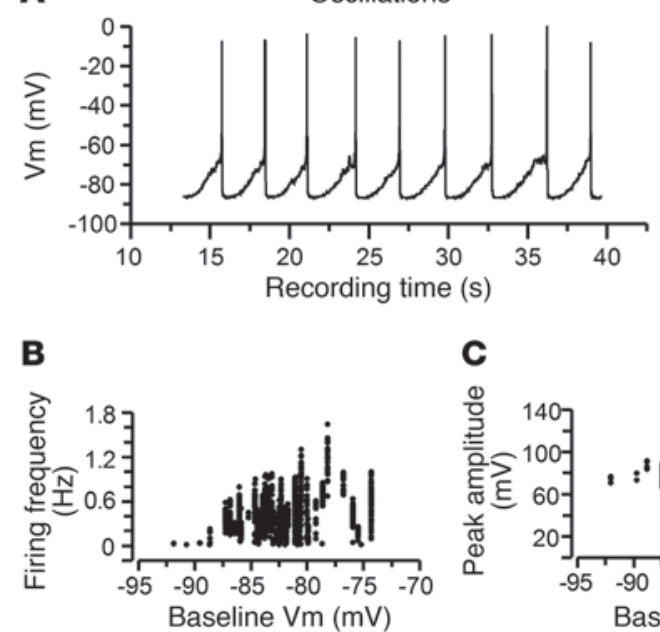

C

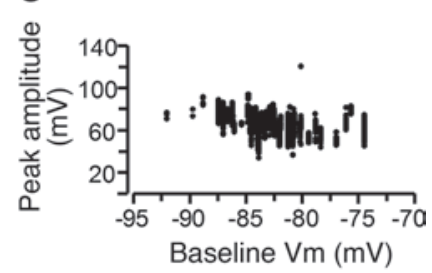

D

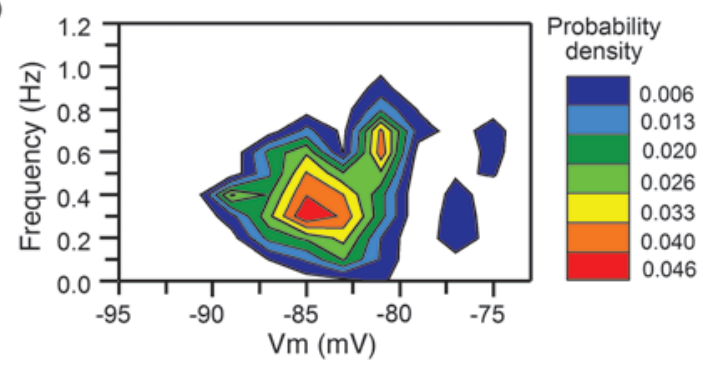

illustrated by a representative recording of a cell with a mean oscillation cycle of $2.7 \mathrm{~s}$ that deviated $80 \mathrm{mV}$ from baseline (Figure 1A). The frequency of $\mathrm{Vm}$ oscillations varied markedly among cells $(0.01-1.6 \mathrm{~Hz}$; mean, $0.44 \pm 0.01 \mathrm{~Hz} ; n=73)$ and was commonly stable during recording at $22^{\circ} \mathrm{C}$. At $35^{\circ} \mathrm{C}$, spontaneous oscillations persisted (mean oscillatory cycle, $1.64 \mathrm{~s}$; baseline $\mathrm{Vm},-81 \mathrm{mV}$; Figure 1A, inset), although elevated temperature significantly shortened the stable recording period (1-2 minutes). In a proportion of cells (15\%), periods of moderate Vm oscillations were interrupted by intermittent silent periods less than $5 \mathrm{~s}$ in duration (Figure 2C). The distribution of oscillation frequency versus mean baseline $\mathrm{Vm}$ displayed a voltage threshold for electrical excitability of $-87 \mathrm{mV}$, below which cells were quiescent (Figure 1B). Depolarization from threshold increased oscillation frequency; however, at potentials positive to $-77 \mathrm{mV}$, oscillation frequency declined. Conversely, the amplitude distribution showed little relationship with mean baseline Vm, displaying only a slight trend toward decrease upon depolarization (Figure 1C). We binned the data and calculated a probability density distribution to quantify the probability of intrinsic oscillatory activity. Transformation of the data presented on a $2 \mathrm{D}$ contour plot showed behavior characteristic of a voltage oscillator: a voltage threshold for activity $(\mathrm{Vm}, \geq-87 \mathrm{mV})$ and a dependency of frequency on voltage (Figure 1D). In addition, the data revealed either bistability to the ZG cell, the probability of finding the ZG cell in 1 of 2 electrical states, or the presence of 2 distinct but unequal ZG cell populations that differed in resting $\mathrm{Vm}$ and oscillation frequency. Given the well-delineated voltage threshold and the voltage dependence of oscillation frequency, we concluded that the ZG cell behaves as an electrical oscillator.

\section{Figure 1}

ZG cells are electrically excitable. (A) Representative current clamp recording of a ZG cell within an adrenal slice generating spontaneous Vm oscillations of low periodicity, and the calculated mean cycle waveform (see Methods) at $22^{\circ} \mathrm{C}$ and at $35^{\circ} \mathrm{C}$ (inset). (B) Average oscillation frequency versus baseline $\mathrm{Vm}$, both determined per cell (see Methods) over recording of 3-10 minutes duration $(n=85)$. (C) Average peak amplitude per cell (determined from the same oscillation analysis as above) versus baseline $\operatorname{Vm}(n=73)$. (D) Average oscillation frequency per cell was binned to calculate probability density distribution of oscillation frequency versus baseline $\mathrm{Vm}$. The 2D contour plot shows behavior of an electrical oscillator with a voltage threshold for activity and a voltage dependence to oscillatory activity.
Intrinsic oscillatory activity depends on Cav3.2 currents. Spontaneous $\mathrm{Vm}$ oscillations of low frequency can be supported by $\mathrm{Ca}^{2+}$ currents carried by low- or high-voltage activated $\mathrm{Ca}^{2+}$ channels. For example, in central neurons $(33,34)$, adrenal chromaffin cells $(35)$, and cardiomyocytes of the sinoatrial node (36), L-type (Cav1.x) $\mathrm{Ca}^{2+}$ channels carry important pacemaker current that support spontaneous low-frequency oscillations; in thalamacortical neurons, Cav3.x Ca ${ }^{2+}$ channel currents serve a similar role $(37,38)$. Accordingly, we used pharmacological blockade to assay the contributions of Nav1.x, Cav1.x, and Cav3.x channel families to lowfrequency oscillations in ZG cells. Tetrodotoxin (TTX) delivered at concentrations that would be expected to fully block TTX-sensitive (Nav1.0-Nav1.4 and Nav1.6-Nav1.7) and TTX-insensitive (Nav1.5) Na channels (100 nM and $10 \mu \mathrm{M}$, respectively) and inhibit TTXresistant (Nav1.8-Nav1.9) Na channels $(60 \mu \mathrm{M})(39)$ did not slow oscillation frequency (Figure 2A). Oscillation frequency was also refractory to nifedipine, a Cav1.x channel blocker. Although block of Cav1.x channels by dihydropyridines is strongly voltage dependent, requiring higher doses to fully block channels at hyperpolarized voltages $(40,41)$, we found that neither $100 \mathrm{nM}$ nor $3 \mu \mathrm{M}$ nifedepine was effective in reducing oscillation frequency (Figure 2B). In contrast, $\mathrm{Ni}^{2+}$ reliably silenced $V \mathrm{~m}$ oscillations at $50 \mu \mathrm{M}$ (Figure $2 \mathrm{C}$ ), and at $10 \mu \mathrm{M}$ reduced oscillation frequency by $34 \% \pm 9 \%$ $(n=5)$, a dose effect that showed selectivity for the most $\mathrm{Ni}^{2+}$-sensitive Cav3.x family member, Cav3.2 channels (42).

To further test the importance of Cav3.2 channel activity for Vm oscillations, we used a model ZG cell derived from a human adrenal tumor (H295R) that lacks expression of some ionic conductances, including Cav3.2 channels. We found that H295R cells had a resting $\mathrm{Vm}$ of approximately $-20 \mathrm{mV}$, were nonexcitable, and 

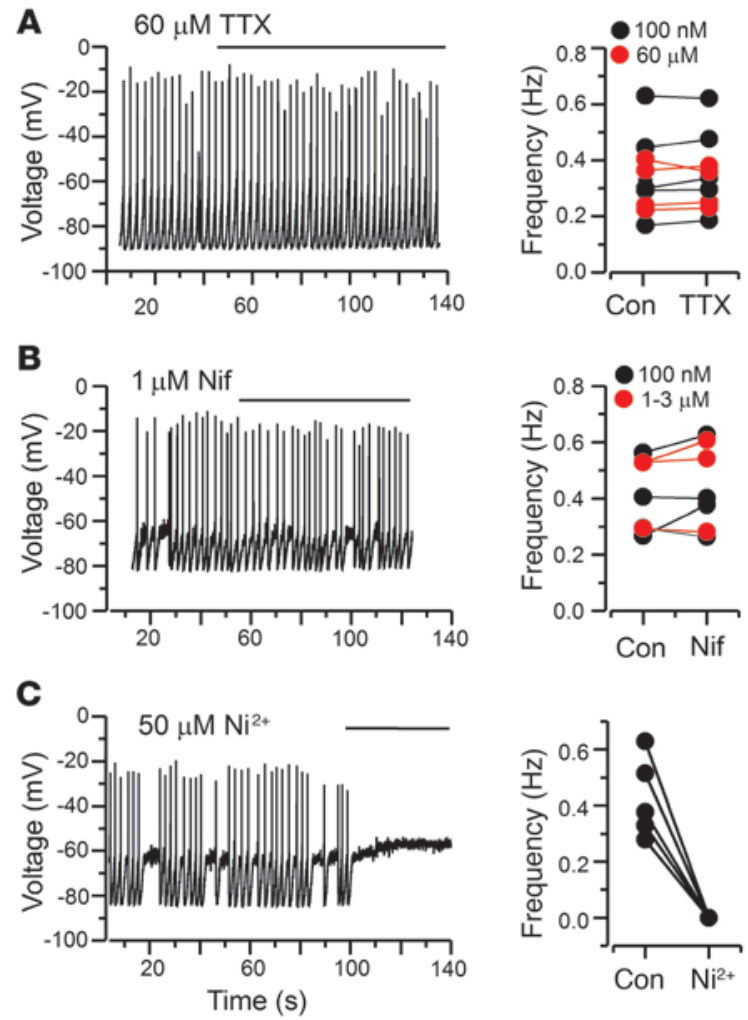

displayed a passive response to DC current injection that produced rectilinear shifts in Vm. In contrast, H295R cells expressing Cav3.2 channels displayed a regenerative response to DC current injection, generating Vm oscillations of low frequency (Supplemental Figure 1; supplemental material available online with this article; doi:10.1172/JCI61996DS1). Notably, cells remained quiescent at baseline voltages negative to $-90 \mathrm{mV}$ and positive to $-60 \mathrm{mV}$, in accord with a voltage threshold and a discrete voltage range within which spontaneous $\mathrm{Vm}$ oscillations were detected in native ZG cells. Taken together, our results suggest that $\mathrm{Vm}$ oscillations in ZG cells may be low-threshold $\mathrm{Ca}^{2+}$ potentials.

Because the ZG layer represents a small proportion of the adrenal cortex, we isolated this layer using laser capture microdissection and used quantitative RT-PCR to determine the $\mathrm{Ca}^{2+}$ transcripts expressed in the dissected ribbons of adrenal tissue. We detected only 1 transcript of the Cav3.x $\mathrm{Ca}^{2+}$ channel family, encoding Cav3.2 channels, in agreement with previous reports indicating that Cav3.2 was the predominant T-type transcript expressed in ZG cells of other species. Nevertheless, we detected several transcripts encoding L-type $\mathrm{Ca}^{2+}$ channels, Cav1.1, Cav1.2, and Cav1.3 (Supplemental Figure 2). Because our dissected tissue contained contiguous adrenal capsule and some zona fasciculata contamination, and because the $Z G$ is the most highly vascularized zone within the adrenal, we recorded $\mathrm{Ca}^{2+}$ channel currents in $\mathrm{ZG}$ cells to test for functional expression of these channel transcripts.

$\mathrm{Ca}^{2+}$ currents in ZG cells were robust. Currents elicited from a holding potential $\left(\mathrm{V}_{\mathrm{H}}\right)$ of $-90 \mathrm{mV}$ were large, slow in onset at a test pulse of $-60 \mathrm{mV}$, and rapidly inactivated during a 100-ms depolarization to $+10 \mathrm{mV}$ (Figure $3 \mathrm{~A}$ ), behavior characteristic of T-type $\mathrm{Ca}^{2+}$ channels. The current-voltage relationship, a composite of 10 recorded cells, peaked at $-40 \mathrm{mV}$ and was reduced more than 5-fold

\section{Figure 2}

ZG cell oscillations depend on a $\mathrm{Ni}^{2+}$-sensitive current. Perfusion application of TTX to target Nav1.x, nifedipine to target Cav1.x, and $\mathrm{Ni}^{2+}$ to target Cav3.x. (A) Representative current clamp recording of a ZG cell stably oscillating $1 \mathrm{~min}$ before and during bath exposure to $60 \mu \mathrm{M}$ TTX (rendering block of TTX-sensitive and insensitive Nav1 channels). Mean oscillation frequency of each of 9 cells before and after exposure to TTX at $100 \mathrm{nM}(n=5)$ or $60 \mu \mathrm{M}(n=4)$ is also shown. (B) Vm oscillations recorded before and during bath exposure to $1 \mu \mathrm{M}$ nifedipine (NIF). Mean oscillation frequency of each recorded cell calculated before and after exposure to nifedepine at $100 \mathrm{nM}(n=4)$ or 1-3 $\mu \mathrm{m}$ $(n=3)$ is also shown. (C) Example of a cell with periods of rhythmic oscillations interrupted by intermittent periods of silence, before and after bath exposure to $50 \mu \mathrm{M} \mathrm{Ni}{ }^{2+}$. Mean oscillation frequency was silenced by $\mathrm{Ni}^{2+}$ in all recorded cells $(n=6)$. when $\mathrm{Ca}^{2+}$ currents were elicited from a $\mathrm{V}_{\mathrm{H}}$ of $-50 \mathrm{mV}$, at which few T-type $\mathrm{Ca}^{2+}$ channels are available to open (Figure $3 \mathrm{~A}$ ). Consistent with the dominant expression of T-type $\mathrm{Ca}^{2+}$ currents, neither nifedipine, an L-type $\mathrm{Ca}^{2+}$ channel blocker, nor (S)-(-)BAYK8644, an L-type $\mathrm{Ca}^{2+}$ channel activator, altered the magnitude or the kinetics of the recorded $\mathrm{Ca}^{2+}$ currents (Figure 3B). Addition of $\mathrm{Ni}^{2+}(1-100$ $\mu \mathrm{M})$ to the bath solution produced a dose-dependent inhibition of $\mathrm{Ca}^{2+}$ currents with an $\mathrm{IC}_{50}$ of $22.5 \mu \mathrm{M}$ (Figure $3 \mathrm{C}$ ). Inhibition of mouse $\mathrm{ZG}$ currents by $\mathrm{Ni}^{2+}$ was independent of the voltage protocol used to elicit $\mathrm{Ca}^{2+}$ currents (step or tail), and the calculated $\mathrm{IC}_{50}$ was similar to the $9.2 \mu \mathrm{M} \mathrm{IC} \mathrm{I}_{50}$ for $\mathrm{Ni}^{2+}$ inhibition of recombinant Cav3.2 channels expressed in HEK293 cells (Figure 3D). We conclude that the functional $\mathrm{Ca}^{2+}$ currents expressed in mouse ZG cells are carried by Cav3.2 channels.

Plasma $\mathrm{K}^{+}$and Ang II regulate oscillation frequency. Both plasma $\mathrm{K}^{+}$and Ang II are major regulators of aldosterone production in vivo. We tested whether these physiological agonists also modulate intrinsic oscillatory activity in ZG cells. We found that decreasing $\mathrm{K}^{+}$from 3 to $2 \mathrm{mM}$ in the bath solution hyperpolarized the baseline $\mathrm{Vm}$ by $-8.0 \pm 2 \mathrm{mV}$ and was accompanied by an approximately $30 \% \pm 3 \%$ decrease in oscillation frequency (Figure 4 , $\mathrm{A}$ and $\mathrm{C} ; n=5$ ). Conversely, increasing $\mathrm{K}^{+}$from 3 to $5 \mathrm{mM}$ in the bath solution depolarized the baseline $\mathrm{Vm}$ by $9 \pm 1 \mathrm{mV}$ with an attendant $43 \% \pm 8 \%$ increase in oscillation frequency (Figure $4, \mathrm{~B}$ and $\mathrm{D} ; n=5)$. In addition, we found that the shape of the oscillatory cycle was changed by $\mathrm{K}^{+}$. The expanded traces - calculated average cycles from the voltage recordings (see Methods) and peak aligned - suggest that depolarization evoked by $5 \mathrm{mM}$ $\mathrm{K}^{+}$preferentially increased the rate of post-spike depolarization. The measured changes in interspike $\mathrm{Vm}$ affected by extracellular $\mathrm{K}^{+}$are in agreement with previous reports showing that the $\mathrm{Vm}$ 

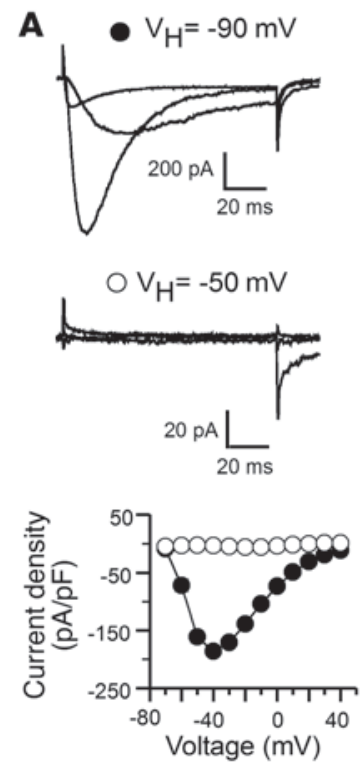

B
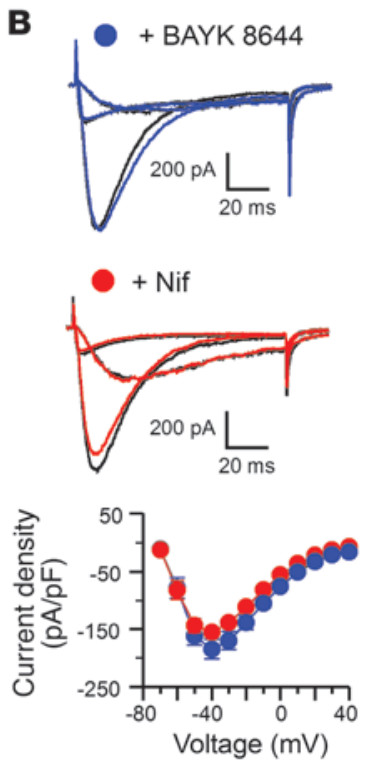
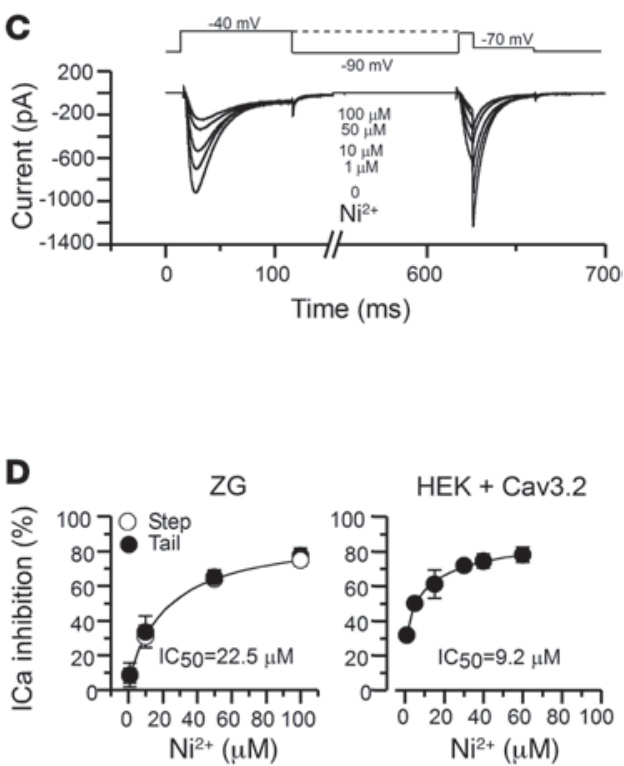

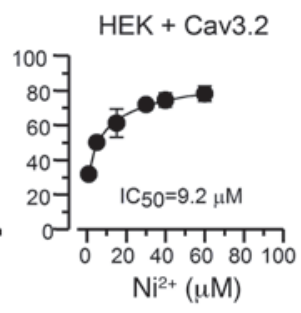

Figure 3

ZG Ca ${ }^{2+}$ currents are robust and Cav3.2-like. (A) $\mathrm{Ca}^{2+}$ currents evoked by $100-\mathrm{ms}$ steps from -70 to $+40 \mathrm{mV}$ in $10-\mathrm{mV}$ increments applied every $6 \mathrm{~s}$ from a $\mathrm{V}_{\mathrm{H}}$ of -90 or $-50 \mathrm{mV}$. Shown are representative currents evoked by steps to $-60,-40$, or $+10 \mathrm{mV}$ from a $\mathrm{V}_{\mathrm{H}}$ of -90 or $-50 \mathrm{mV}$ to reduce Cav3.x channel availability. Current-voltage relationship was constructed from peak current densities $(n=16)$. (B) Representative currents as in A evoked in the presence of $1 \mu \mathrm{M}(\mathrm{S})$-(-)BAYK8644 or $1 \mu \mathrm{M}$ nifedipine from a $\mathrm{V}_{\mathrm{H}}$ of $-90 \mathrm{mV}$. Current-voltage relationships were constructed from peak current densities ( $n=8$ per group). (C) $\mathrm{Ca}^{2+}$ currents evoked by step (100-ms to $-40 \mathrm{mV}$ ) or tail current (35-ms repolarization to $-70 \mathrm{mV}$ following 9-ms step to $-40 \mathrm{mV}$ ) voltage protocols from a $\mathrm{V}_{\mathrm{H}}$ of $-90 \mathrm{mV}$ applied every $6 \mathrm{~s}$, in the absence, then presence, of $\mathrm{Ni} 2+$ in the bath solution from 1 to $100 \mu \mathrm{M}$ (mean \pm SEM). (D) $\mathrm{Ni}^{2+}$ inhibition curves of $\mathrm{Ca}^{2+}$ channel currents (ICa). Percent inhibition was calculated as measured current relative to maximal current recorded in the absence of $\mathrm{Ni}^{2+}$. Datasets were fitted with a logistic equation yielding $\mathrm{IC}_{50} 22.5 \mu \mathrm{M}(n=6)$ for $\mathrm{Ni}^{2+}$ block of $\mathrm{Ca}^{2+}$ currents expressed in ZG cells and $9.2 \mu \mathrm{M}(n=6)$ for block of recombinant Cav3.2 currents expressed in HEK293 cells.

of isolated ZG cells does not deviate greatly from the equilibrium potential for $\mathrm{K}^{+}(10)$. Depolarizing current injection into a single cell to produce graded changes in baseline $\mathrm{Vm}$ generated graded increases in oscillation frequency that were accompanied by a commensurate reduction in peak amplitude (Supplemental Figure 3), which suggests that in ZG cells, changing baseline Vm is one mechanism for controlling the frequency of low-threshold $\mathrm{Ca}^{2+}$ potentials. We also found that Ang II dose-dependently increased oscillation frequency with an $\mathrm{EC}_{50}$ for stimulation of $85.2 \pm 32.4 \mathrm{nM}$ and also increased the rate of post-spike depolarization (Figure 4, E and F). However, the Ang II-elicited change in oscillatory activity was not accompanied by a consistent change in baseline Vm or peak amplitude. These data indicate that Ang II may use a different mechanism from that of plasma $\mathrm{K}^{+}$to control low-threshold $\mathrm{Ca}^{2+}$ potentials.

$V m$ oscillations enhance transduction of the $\mathrm{Ca}^{2+}$ signal by Cav3.2 chan$n e l s$. We tested the importance of $\mathrm{Vm}$ oscillations for $\mathrm{Ca}^{2+}$ signal transduction. We recorded $\mathrm{Ca}^{2+}$ currents in voltage-clamp using voltage commands that replicated calculated averaged oscillatory cycles (see Methods) from a representative recording of a ZG cell spontaneously oscillating in the absence, then presence, of Ang II. Notably, Ang II shortened the mean oscillation cycle from 2.14 to $1.24 \mathrm{~s}$, without altering peak $(-11.9$ to $-13.7 \mathrm{mV})$ or baseline ( -81.4 to $-80.9 \mathrm{mV}) \mathrm{Vm}$ values. Thus, either 4 or 8 oscillatory cycles (control or Ang II oscillatory command, respectively) were completed during a 10-s recording period (Figure $5 \mathrm{~A})$. To record the response of Cav3.2 channels to oscillatory voltage commands, we used recording conditions that permitted the identification of Cav3.2 channel currents in Figure 3, namely, leak subtraction and solutions designed to eliminate $\mathrm{K}^{+}$current contamination (internal, $\mathrm{CsCl}$ and tetrabutyammonium chloride [TBACl]; external, tetraethyamonium chloride [TEACl]). Using either voltage command, $\mathrm{Ca}^{2+}$ current was elicited during the rising phase of each oscillatory cycle, increasing to a maximum value well after the peak of the waveform (Figure 5A), in agreement with an increased driving force on slowly closing Cav3.2 channels during the repolarization phase of each cycle. We found that peak current, as well as total current per cycle, tended to decrease with repetitive cycle deliver results that are consistent with cumulative channel inactivation (Figure 5B). However, total $\mathrm{Ca}^{2+}$ entry per Ang II cycle was greater than that of the control, which suggests that the slower initial rate of repolarization (see the expanded waveform overlay in Figure 5A) extended the time for repeated channel openings. Greater $\mathrm{Ca}^{2+}$ entry per cycle and more cycles per unit time led to a remarkable $140 \%$ increase in $\mathrm{Ca}^{2+}$ current elicited by the Ang II oscillatory voltage command. Although $\mathrm{Ca}^{2+}$ current carried by L-type $\mathrm{Ca}^{2+}$ channels was not evident using conventional step-like voltage commands (Figure 3 , $\mathrm{A}$ and $\mathrm{B}$ ), we used $\mathrm{Ni}^{2+}$ to reveal any contribution of L-type channels to the complex currents elicited by the oscillatory waveforms (Figure $5 \mathrm{C}$ ). $\mathrm{Ni}^{2+}$ blocked $80 \%$ of the total recorded current, consistent with $80 \%$ maximal block of recombinant Cav3.2 channels and corroborated the comparable $120 \%$ increase in Cav3.2 current elicited by the Ang II voltage command (Figure 5D). To evaluate the relative contribution of $\mathrm{Ni}^{2+}$-sensitive $\mathrm{Ca}^{2+}$ currents to the spontaneous depolarization between spikes, we quantified 

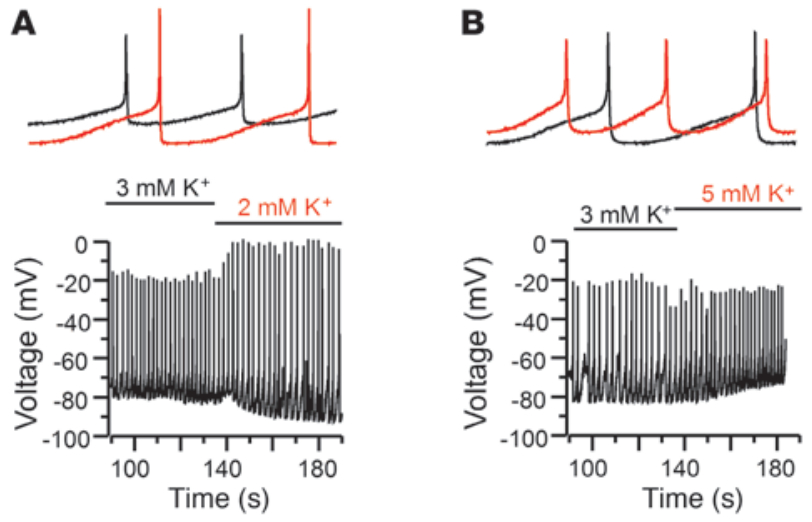

C
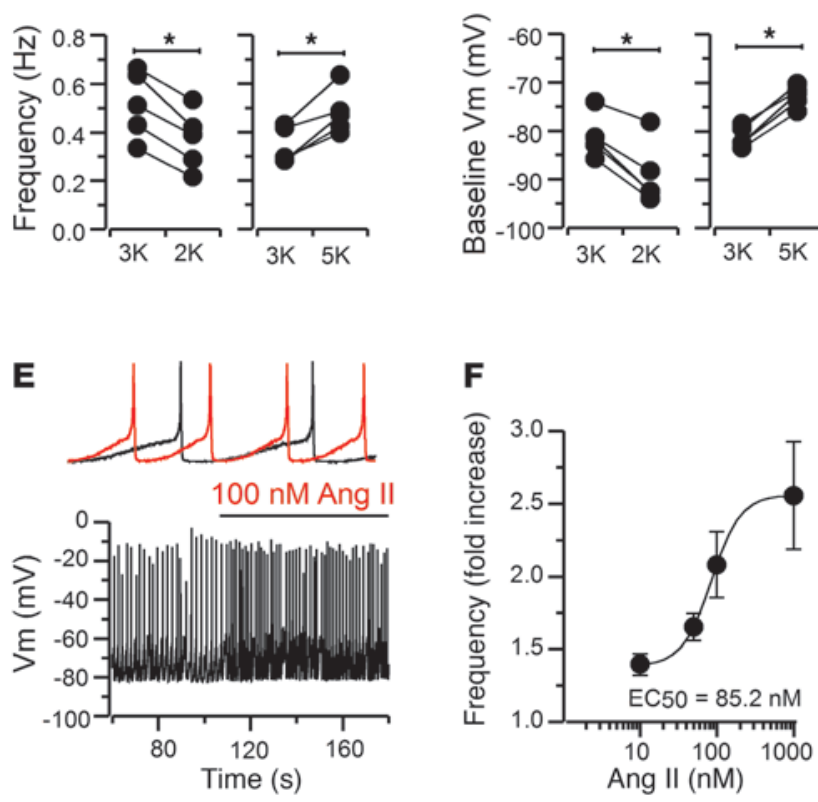

and averaged the $\mathrm{Ni}^{2+}$-sensitive current during the interspike intervals elicited by the Ang II voltage command (Figure 5E). The amplitude of the $\mathrm{Ca}^{2+}$ current measured at 3 different voltages was $-2.1 \pm 0.2 \mathrm{pA}$ at $-80 \mathrm{mV},-3.1 \pm 0.2 \mathrm{pA}$ at $-70 \mathrm{mV}$, and $-2.3 \pm 0.3 \mathrm{pA}$ at $-64 \mathrm{mV}$, showing no voltage dependence over this $16-\mathrm{mV}$ range. Therefore, Cav3.2 current is required for Vm oscillations in ZG cells, but does not drive the depolarization phase of the oscillatory cycle. Thus, we conclude that the intrinsic oscillatory behavior of the ZG cell allows Cav3.2 channels to transduce a $\mathrm{Ca}^{2+}$ signal that can be amplified by Ang II.

\section{Discussion}

Our studies showed that ZG cells retained within an acute adrenal slice were not quiescent, but expressed an intrinsic capacity to generate a recurring electrical signal, producing spontaneous $\mathrm{Vm}$ oscillations of low periodicity. Several lines of evidence suggested that Cav3.2 $\mathrm{Ca}^{2+}$ current is necessary for Vm oscillations in ZG cells. First, $\mathrm{Vm}$ oscillations were refractory to drugs that either block voltage-gated $\mathrm{Na}$ channels or modulate high-voltage activated $\mathrm{Ca}$ channels, but were halted by $\mathrm{Ni}^{2+}$ block of Cav3.2 channels. Second, mouse $\mathrm{ZG} \mathrm{Ca}{ }^{2+}$ currents were robust: current was slowly activating and deactivating at modest test potentials, rapidly inactivating at

\section{Figure 4}

External $\mathrm{K}^{+}$and Ang II change ZG cell oscillatory behavior. Representative current clamp recordings of $Z G$ cells oscillating in standard buffer $\left(3 \mathrm{mM} \mathrm{K}^{+}\right)$and after $\mathrm{K}^{+}$substitution with $2 \mathrm{mM}(\mathbf{A})$ or $5 \mathrm{mM}$ (B) $\mathrm{K}^{+}$. Expanded traces are calculated average cycles from same voltage recordings. (C and $\mathbf{D}$ ) Average oscillation frequency per cell (C) and average baseline $\mathrm{Vm}(\mathrm{D})$, calculated before and after hyperpolarization with $2 \mathrm{mM} \mathrm{K}^{+}(n=5)$ or depolarization with $5 \mathrm{mM} \mathrm{K}^{+}$ $(n=5)$. (E) Representative current clamp recording of a cell spontaneously oscillating before and during exposure to $100 \mathrm{nM}$ Ang II. Expanded traces are calculated average cycles from the same voltage recording. (F) Average oscillation frequency (calculated before and after exposure to a single concentration of Ang II), expressed as fold increase over the pre-Ang II frequency. Data points represent mean \pm SEM and were fitted with a logistic equation. $\mathrm{EC}_{50}=85.2 \mathrm{nM}$ ( $n=5$ per concentration). ${ }^{*} P<0.05$.

strong test potentials, and blocked by $\mathrm{Ni}^{2+}$ with an $\mathrm{EC}_{50}$ of $22.5 \mu \mathrm{M}$, characteristics that mimic heterologously expressed Cav3.2 channels. Third, the Cav3.2 message was highly expressed in the microdissected ZG layer of the mouse adrenal slice. Finally, exogenous expression of Cav3.2 channels in a model ZG cell lacking $\mathrm{Ca}^{2+}$ current restored low-threshold $\mathrm{Vm}$ oscillations to these cells.

Although $\mathrm{Ni}^{2+}$ block of Cav3.2 current silenced $\mathrm{Vm}$ oscillations in ZG cells, our data do not support a pacemaking role for this current in the depolarization phase of the oscillatory cycle. During the interspike interval, Cav3.2 current remained relatively constant (2-3 pA) and was less than $11 \%$ of the current that would be necessary $(26 \mathrm{pA})$ to raise the membrane voltage from -80 to -64 $\mathrm{mV}$, given the modest input resistance of the $Z \mathrm{G}$ cell $(610 \pm 38 \mathrm{M} \Omega$; $n=23$ cells). Rather, our data support a role for Cav3.2 $\mathrm{Ca}^{2+}$ current in modulating the repolarization phase of the oscillatory cycle, as $\mathrm{Ni}^{2+}$ elicited a slowing of oscillatory frequency at $10 \mu \mathrm{M}$ (in agreement with $\mathrm{IC}_{50}$ for $\mathrm{Ni}^{2+}$ inhibition of Cav3.2 current) and a marked depolarization at $50 \mu \mathrm{M}$; these effects suggest the importance of a $\mathrm{Ca}^{2+}$-activated $\mathrm{K}^{+}$current to the oscillatory cycle, as is observed in neurons of the suprachiasmatic nucleus (33). Thus, the question of what additional currents combine with Cav3.2 currents to generate $\mathrm{Vm}$ oscillations remains to be answered.

In other systems, such as reticular thalamic or thalamocortical neurons, Vm oscillations of low frequency are supported by $\mathrm{K}^{+}$ channel leak activity and Cav3.x steady-state "window currents," a product of the overlapping voltage range over which channels activate and inactivate $(43,44)$. Because the Cav3.x window current has a bell-shaped dependence on voltage, oscillation frequency depends on the voltage region of its steady-state expression, which can be altered by modifying either of the steady-state voltage relationships for channel activation or inactivation or by adjusting $\mathrm{Vm}$ with K leak. In ZG cells, both extracellular $\mathrm{K}^{+}$and Ang II increased oscillation frequency. We postulate that $\mathrm{K}^{+}$-induced depolarization moves the baseline $\mathrm{Vm}$ of the $\mathrm{ZG}$ cell into a voltage range of enhanced Cav3.2 steady-state window current and that Ang II, by its known actions to induce a hyperpolarizing shift in the voltage dependence of Cav3.2 channels (45-48), expands the voltage region of steady-state window current expression.

What is the function of Vm oscillations in ZG cells? Our results show that the gating properties of Cav3.2 channels permit measurable and repeated cycles of $\mathrm{Ca}^{2+}$ entry into the $Z G$ cell in response to voltage commands that replicate intrinsic ZG cell oscillatory activity. Moreover, by a combination of 
A

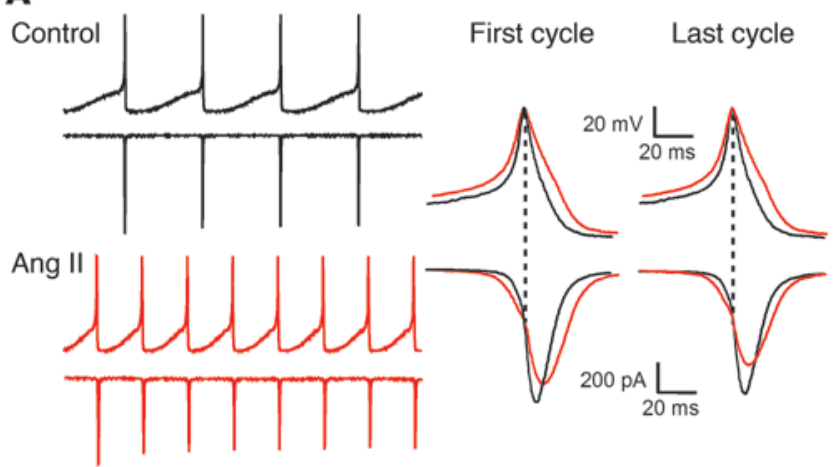

C

Control

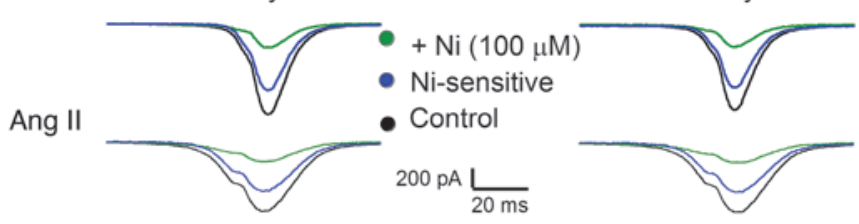

E
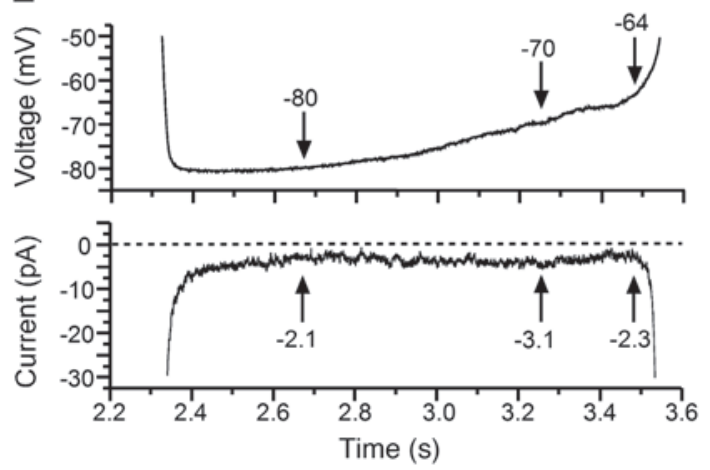

B

Control Peak current Current area

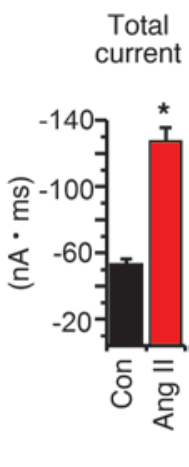

Ang 11
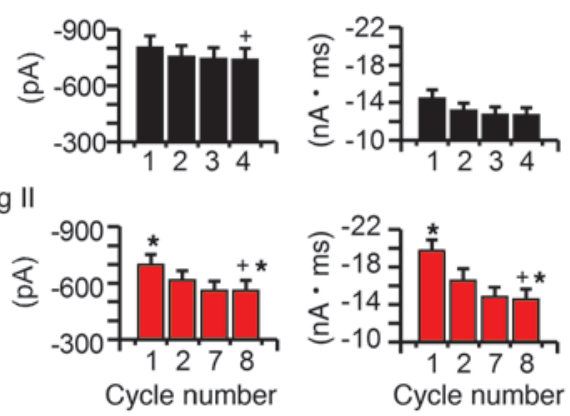

Control Peak current

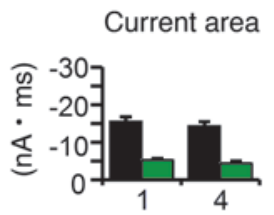

Ang II
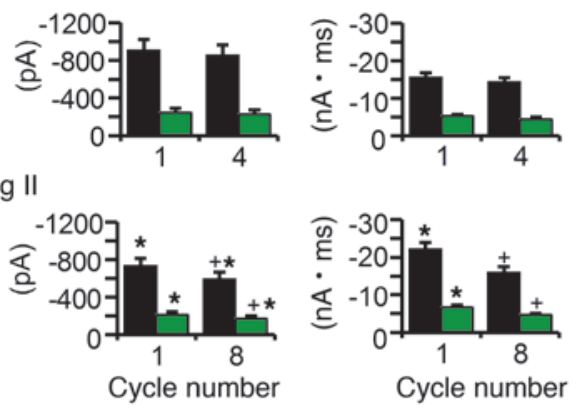

current

$(\mathrm{Ni}-$ sensitive)

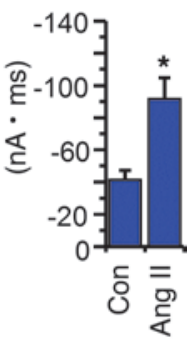

Total

\section{Figure 5}

Vm oscillations increase $\mathrm{Ca}^{2+}$ entry carried by Cav3.2 channels. (A) Vm oscillatory voltage commands generated from voltage recordings to construct average cycles (see Methods) that represent control and Ang II oscillatory activity. 4 (control; $2.14 \mathrm{~s}$ ) or 8 (Ang II; $1.24 \mathrm{~s}$ ) Vm cycles were delivered in $10 \mathrm{~s}$ (top traces). Mean $\mathrm{Ca}^{2+}$ currents evoked sequentially by control and Ang II voltage commands $(n=16)$ are shown below. Also displayed are magnified representations of the mean current elicited during first and last cycles. (B) Cycle comparison of averaged peak Ca ${ }^{2+}$ currents and averaged $\mathrm{Ca}^{2+}$ current areas. Peak current and current area per cycle per cell $(n=16)$ were calculated and averaged. Average Ca ${ }^{2+}$ current area summed across cycle number (i.e., total current) evoked by Ang II command was $240 \%$ that of control command. (C) $\mathrm{Ni}^{2+}-$ sensitive Cav3.2 $\mathrm{Ca}^{2+}$ current. Mean $\mathrm{Ca}^{2+}$ currents recorded in the absence or presence of $100 \mu \mathrm{M} \mathrm{Ni}^{2+}$ evoked by the first or last $\mathrm{Vm}$ cycle. The blue difference current defines the $\mathrm{Ni}^{2+}$-sensitive Cav3.2 current, which, because of incomplete block by $\mathrm{Ni}^{2+}$, was an underestimate. (D) Average peak $\mathrm{Ca}^{2+}$ current and average $\mathrm{Ca}^{2+}$ current area compared between first and last cycle, showing persistent $\mathrm{Ni}^{2+}$ block $(n=6)$. Average $\mathrm{Ni}^{2+}$-sensitive component (Cav3.2) of $\mathrm{Ca}^{2+}$ current area summed across cycle number (i.e., total $\mathrm{Ni}^{2+}$-sensitive current) evoked by Ang $\mathrm{Il}$ command was $220 \%$ that of control. (E) Mean $\mathrm{Ni}^{2+}$-sensitive current averaged during interspike intervals elicited by Ang II command $(n=6) .{ }^{+} P<0.05$ vs. first cycle; ${ }^{\star} P<0.05$ vs. control. Bars represent mean \pm SEM.

enhanced frequency and a slower initial rate of repolarization, Ang II dose-dependently increased $\mathrm{Ca}^{2+}$ entry by $140 \%$ over that elicited by the control voltage waveform. Conversely, if over each 10 -s recording period the average voltage was delivered as a rectilinear voltage pulse, the averaged voltages differed by only $1.6 \mathrm{mV}$ and remained well within the range in which steadystate Cav3.2 channel opening is negligible (control, $-74.9 \mathrm{mV}$; Ang II, $-73.3 \mathrm{mV}$ ). Therefore, we suggest that this ability of the ZG cell to behave as an intrinsic oscillator (which, to our knowledge, has not been previously characterized) allows small changes in voltage to be amplified in voltage and time, and thus provides the platform for Cav3.2 channels to transduce a substantial steady-state $\mathrm{Ca}^{2+}$ current that is both compatible with the lengthy time course of steroidogenesis and able to be amplified by aldosterone secretagogues. In addition, our data suggest that Vm oscillations could explain the remarkable sensitivity of aldosterone production in vivo to small incremental changes $(0.1 \mathrm{mEq} / \mathrm{l})$ in plasma $\mathrm{K}^{+}(49)$. We conclude that these findings provide a paradigm shift in our understanding of the mechanism by which $\mathrm{Ca}^{2+}$ entry is regulated in $\mathrm{ZG}$ cells and could 
offer new pharmacological targets for disease states in which the renin-angiotensin-aldosterone system is elevated and aldosterone is pathogenic, such as low-renin hypertension, chronic kidney disease, and heart failure.

\section{Methods}

Animals. Male C57BL/6 mice were purchased from Jackson Laboratory and housed on a 12-hour light/12-hour dark cycle in a temperature- and humidity-controlled environment. Adult mice (35-55 days old) were used to ensure mature adrenal morphology and well-defined zonation.

Tissue slice preparation. Adrenal glands were harvested from mice deeply anesthetized with ketamine (15 mg i.p.) and kept in ice-cold low-Ca ${ }^{2+}$ bicarbonate-buffered saline (BBS; $10 \mathrm{mM}$ glucose, $140 \mathrm{mM} \mathrm{NaCl}, 2 \mathrm{mM} \mathrm{KCl}, 5$ $\mathrm{mM} \mathrm{MgCl}_{2}, 0.1 \mathrm{mM} \mathrm{CaCl}_{2}$, and $26 \mathrm{mM} \mathrm{NaHCO}_{3}$ bubbled with $95 \% \mathrm{O}_{2}$ and $5 \% \mathrm{CO}_{2}$ ). Adrenals were desheathed of the surrounding fat tissue, embedded in low-melting temperature agar $(2.5 \%$ in BBS), and sectioned ( $80 \mu \mathrm{m})$ using a DSK supermicroslicer (Ted Pella Inc.). The slices were incubated at $35^{\circ} \mathrm{C}$ in BBS for 30 minutes, then kept at room temperature for the remainder of the experiment. Data were collected from 1-4 cells per mouse.

Cav3.2 channel transfection. HEK293 embryonic kidney cells were cultured in DMEM/F12 media with 10\% fetal bovine serum and 1\% penicillin/ streptomycin. JetPEI reagent (Polyplus Transfection) was used to transfect HEK293 cells following the manufacturer's protocol. For transfection, we used $0.5 \mu \mathrm{g}$ GFP plasmid, $2.5 \mu \mathrm{g}$ Cav3.2 plasmid, and $6 \mu \mathrm{J}$ JetPEI reagent per well of a 6-well plate. H295R human adrenocortical carcinoma cells were cultured in DMEM/F12 containing $10 \%$ cosmic calf serum, $1 \mu \mathrm{g} / \mathrm{ml}$ gentamicin, and $1 \%$ penicillin/streptomycin. All culture vessels for H295R cells were coated with sterile $0.1 \%$ gelatin and washed with $1 \times$ phosphatebuffered saline before use. LipoD293 reagent (Signagen) was used to transfect H295R cells following the manufacturer's protocol. For transfection, we used $0.5 \mu \mathrm{g}$ GFP plasmid, $2.5 \mu \mathrm{g}$ Cav3.2 plasmid, and $6 \mu \mathrm{L}$ LipoD reagent per well of a 6-well plate. All cells were used for electrophysiological experiments 24-48 hours after transfection.

Whole-cell recording. Adrenal slices were submerged in a recording chamber, secured with a slice anchor, and visualized using an Examiner.A1 microscope (Zeiss) with a $\times 40$ objective. Cells located near the surface of the slice just beneath the capsule were targeted for recording, based on anatomic location and characteristic shape. Electrophysiology recordings were obtained at room temperature using patch electrodes (3-5 M $\Omega$ ) and an Axopatch 200B amplifier (Molecular Devices). Data acquisition was performed using pCLAMP 10.3 (Molecular Devices).

Voltage recording and analysis. Slices were perfused with a standard external solution containing $140 \mathrm{mM} \mathrm{NaCl}, 3 \mathrm{mM} \mathrm{KCl}, 10 \mathrm{mM}$ HEPES, $2 \mathrm{mM}$ $\mathrm{MgCl}_{2}, 2 \mathrm{mM} \mathrm{CaCl}_{2}$, and $10 \mathrm{mM}$ glucose ( $\mathrm{pH}$ 7.3). The pipette (intracellular) solution contained $135 \mathrm{mM} \mathrm{KMeSO}_{3}, 4 \mathrm{mM} \mathrm{NaCl}, 10 \mathrm{mM}$ HEPES, $1 \mathrm{mM}$ $\mathrm{MgCl}_{2}, 0.5 \mathrm{mM}$ EGTA, $3 \mathrm{mM} \mathrm{Mg-ATP}$, and $0.3 \mathrm{mM}$ Tris-GTP (pH 7.2). Voltage traces were acquired at $2.5 \mathrm{kHz}$ filtered at $1 \mathrm{kHz}$ with an Axopatch 200B integrated low-pass Bessel filter. Baseline membrane voltages were recorded from ZG cells for 2-4 minutes before perfusion application of a second external solution containing either high $\mathrm{K}^{+}(5 \mathrm{mM} \mathrm{KCl}, 138 \mathrm{mM}$ $\mathrm{NaCl})$, low $\mathrm{K}^{+}(2 \mathrm{mM} \mathrm{KCl}, 141 \mathrm{mM} \mathrm{NaCl})$, or a pharmacological agent [100 nM or $60 \mu \mathrm{M}$ TTX, $100 \mathrm{nM}$ or $3 \mu \mathrm{M}$ nifedipine, $100 \mathrm{nM}$ or $1 \mu \mathrm{M}(\mathrm{S})$ (-)BAYK8644), 1-100 $\mu \mathrm{M} \mathrm{Ni}^{2+}$, or $10 \mathrm{nM}$ to $1 \mu \mathrm{M}$ Ang II].

Oscillation analysis. Vm oscillations were mathematically analyzed to determine the frequency distribution, amplitude distribution, and average shape of a cycle. Each cycle was individually analyzed by computing its phase as a function of time. Phase analysis is useful for quantifying the position of an oscillatory system along a closed trajectory. Phase, $\Phi(t)$, was calculated using Equation 1, in which $V_{m}(t)$ is the recorded $V m,\left\langle V_{m}(t)\right\rangle$ is the mean $\mathrm{Vm}$, and $H(x)$ is the Hilbert transform. $\phi(t)=\tan ^{-1}\left(\frac{V_{m}(t)-\left\langle V_{m}(t)\right\rangle}{H\left(V_{m}(t)-\left\langle V_{m}(t)\right\rangle\right)}\right)$

(Equation 1)

A Poincare surface in the Hilbert space was used to define the beginning and end points of each cycle. The time between adjacent crossings of the Poincare surface provided the period for each cycle. Amplitude was determined by subtracting the baseline $\mathrm{Vm}$ of the cell from the maximum Vm observed during a given cycle.

The averaged shape of the Vm oscillation was determined by averaging all observed oscillations. Vm measurements were separated by phase into bins with a width of $2 \pi / 1,000$ radians. The data points within the individual bins were averaged together to generate a mean cycle as a function of phase. The period of this averaged cycle was taken to be the mean period of the observed oscillations.

Analysis of baseline $\mathrm{Vm}$, average oscillation frequency, and average peak amplitude was corroborated using event detection algorithms in Clampfit 10.3 (Molecular Devices Inc.), in which each detected event was assigned an instantaneous frequency (reciprocal of interevent interval) and amplitude. Averages of event frequencies, amplitudes, and baselines were well comparable with average cycle parameters determined by phase analysis described above, but did not provide a mean cycle shape.

Current recording and analysis. Slices were perfused with an external solution that contained $132 \mathrm{mM}$ TEACl, $5 \mathrm{mM}$ dextrose, $32 \mathrm{mM}$ sucrose, $10 \mathrm{mM} \mathrm{CaCl}_{2}, 0.5 \mathrm{mM} \mathrm{MgCl}_{2}$ and $10 \mathrm{mM}$ HEPES (pH 7.4). The pipette (intracellular) solution contained $115 \mathrm{mM} \mathrm{CsCl}, 1 \mathrm{mM} \mathrm{TBACl}, 20 \mathrm{mM}$ HEPES, $1 \mathrm{mM} \mathrm{MgCl} 2,11 \mathrm{mM}$ BAPTA, $0.9 \mathrm{mM} \mathrm{CaCl}_{2}, 3 \mathrm{mM} \mathrm{Mg}$-ATP, and $0.3 \mathrm{mM}$ Tris-GTP (pH 7.2). $\mathrm{Ca}^{2+}$ current traces were acquired at $12.5 \mathrm{kHz}$ and filtered at $2 \mathrm{kHz}$ with an Axopatch 200B integrated low-pass Bessel filter. Fast capacitative transients were minimized online by patch-clamp analog compensation. Residual capacitative and leak currents were removed digitally using scaled hyperpolarizing steps of one-fourth amplitude (P/N4).

To determine current-voltage relationships, currents were evoked by $100-$ $\mathrm{ms}$ steps from -70 to $+40 \mathrm{mV}$ in $10-\mathrm{mV}$ increments delivered every $6 \mathrm{~s}$ from a $\mathrm{V}_{\mathrm{H}}$ of -90 or $-50 \mathrm{mV}$. Voltage protocols were run twice to ascertain baseline stability before drug addition. At each potential, peak current densities were calculated and averaged among cells to construct current-voltage relationships. In some studies, tail current-voltage commands were used to evoke Cav3.2 currents. Tail currents were evoked in response to depolarizing pulses to $-40 \mathrm{mV}\left(9 \mathrm{~ms}\right.$ ) from a $\mathrm{V}_{\mathrm{H}}$ of $-90 \mathrm{mV}$ upon repolarization to $-70 \mathrm{mV}$ (35 ms) delivered every $6 \mathrm{~s}$. Tail currents were fitted to a single exponential plus a constant using the Chebyshev algorithm in Clampfit 10.3 (Molecular Devices). We blanked the first $250 \mu$ s of the 35 -ms fitting region to eliminate any possible contamination with residual capacitative current.

To record Cav3.2 channel activity during Vm oscillations, oscillatory voltage commands that repetitively delivered averaged cycles were constructed from voltage recordings as described above for phase analysis. Currents were sampled at $2.5 \mathrm{kHz}$, and leak subtracted records were analyzed in Clampfit to determine peak amplitude (pA) and area (pA-ms) between cursors, delineating each individual oscillatory cycle within the record, and then values per cycle were averaged among cells. Only cells with suitable stability to be recorded twice with each voltage command (control and Ang II) were included in our analysis.

Statistics. The effects of TTX, nifedipine, $\mathrm{Ni}^{2+}$, and $\mathrm{K}^{+}$on $\mathrm{ZG}$ oscillation frequency and Vm were analyzed using paired Student's $t$ tests. The mean peak current and mean current area elicited by the first and last voltage command cycle were compared using repeated-measures 1-way ANOVA and Bonferroni post-hoc test. Total current and total $\mathrm{Ni}^{2+}$-sensitive current were calculated for each cell under control and Ang II voltage command, and means were 
compared using paired Student's $t$ test. All analysis was performed using 2-tailed tests, and $P$ values less than 0.05 were considered significant.

Study approval. Mice were cared for in accordance with the Guide for the Care and Use of Laboratory Animals, and all experiments were approved by the University of Virginia Animal Care and Use Committee.

\section{Acknowledgments}

We thank Mark Beenhakker for his helpful discussions. This work was supported by NIH grants to P.Q. Barrett (HL_036977, HL_089717) and by grants to C. Hu (National Natural Science
Foundation of China, 31000515; National Basic Research Program of China, 2011CB503703).

Received for publication November 17, 2011, and accepted in revised form March 14, 2012.

Address correspondence to: Paula Q. Barrett, Department of Pharmacology, University of Virginia School of Medicine, 1640 Jefferson Park Ave., Charlottesville, Virginia 22908, USA. Phone: 434.924.5454; Fax: 434.982.3878; E-mail: pqb4b@virginia.edu.
1. Rossi GP. A comprehensive review of the clinical aspects of primary aldosteronism. Nat Rev Endocrinol. 2011;7(8):485-495.

2. Calhoun DA, et al. Resistant hypertension: diagnosis, evaluation, and treatment: a scientific statement from the American Heart Association Professional Education Committee of the Council for High Blood Pressure Research. Circulation. 2008;117(25):e510-e526.

3. Milliez P, Girerd X, Plouin PF, Blacher J, Safar ME, Mourad JJ. Evidence for an increased rate of cardiovascular events in patients with primary aldosteronism. J Am Coll Cardiol. 2005;45(8):1243-1248.

4. Funder JW. Medicine. The genetics of primary aldosteronism. Science. 2011;331(6018):685-686.

5 . Arrighi I, et al. Altered potassium balance and aldosterone secretion in a mouse model of human congenital long QT syndrome. Proc Natl Acad Sci U S A. 2001;98(15):8792-8797.

6. Davies LA, et al. TASK channel deletion in mice causes primary hyperaldosteronism. Proc Natl Acad Sci U S A. 2008;105(6):2203-2208.

7. Heitzmann D, et al. Invalidation of TASK1 potassium channels disrupts adrenal gland zonation and mineralocorticoid homeostasis. EMBO J. 2008;27(1):179-187.

8. Choi $\mathrm{M}$, et al. $\mathrm{K}^{+}$channel mutations in adrenal aldosterone-producing adenomas and hereditary hypertension. Science. 2011;331(6018):768-772.

9. Quinn SJ, Cornwall MC, Williams GH. Electrical properties of isolated rat adrenal glomerulosa and fasciculata cells. Endocrinology. 1987;120(3):903-914.

10. Lotshaw DP. Role of membrane depolarization and T-type Ca2+ channels in angiotensin II and $\mathrm{K}+$ stimulated aldosterone secretion. Mol Cell Endocrinol. 2001;175(1-2):157-171.

11. Aguilera G, Catt KJ. Participation of voltage-dependent calcium channels in the regulation of adrenal glomerulosa function by angiotensin II and potassium. Endocrinology. 1986;118(1):112-118.

12. Barrett PQ, Bollag WB, Isales CM, McCarthy RT, Rasmussen $\mathrm{H}$. Role of calcium in angiotensin II-mediated aldosterone secretion. Endocr Rev. 1989;10(4):496-518.

13. Fakunding JL, Chow R, Catt KJ. The role of calcium in the stimulation of aldosterone production by adrenocorticotropin, angiotensin II, and potassium in isolated glomerulosa cells. Endocrinology. 1979;105(2):327-333.

14. Spat A, Enyedi P, Hajnoczky G, Hunyady L. Generation and role of calcium signal in adrenal glomerulosa cells. Exp Physiol. 1991;76(6):859-885.

15. Rossier MF, Burnay MM, Brandenburger Y, Cherradi N, Vallotton MB, Capponi AM. Sources and sites of action of calcium in the regulation of aldosterone biosynthesis. Endocr Res. 1996;22(4):579-588.

16. Bird IM, Mathis JM, Mason JI, Rainey WE. $\mathrm{Ca}^{2+}$ regulated expression of steroid hydroxylases in H295R human adrenocortical cells. Endocrinology. 1995;136(12):5677-5684.

17. Denner K, Rainey WE, Pezzi V, Bird IM, Bernhardt $\mathrm{R}$, Mathis JM. Differential regulation of 11 beta- hydroxylase and aldosterone synthase in human adrenocortical H295R cells. Mol Cell Endocrinol. 1996;121(1):87-91.

18. Spat A, Hunyady L. Control of aldosterone secretion: a model for convergence in cellular signaling pathways. Physiol Rev. 2004;84(2):489-539.

19. Matsunaga H, Maruyama Y, Kojima I, Hoshi T. Transient $\mathrm{Ca}^{2+}$-channel current characterized by a lowthreshold voltage in zona glomerulosa cells of rat adrenal cortex. Pflugers Arch. 1987;408(4):351-355.

20. Cohen CJ, McCarthy RT, Barrett PQ, Rasmussen H. Ca channels in adrenal glomerulosa cells: $\mathrm{K}^{+}$and angiotensin II increase T-type Ca channel current. Proc Natl Acad Sci U S A. 1988;85(7):2412-2416.

21. Durroux T, Gallo-Payet N, Bilodeau L, Payet MD. Background calcium permeable channels in glomerulosa cells from adrenal gland. J Membr Biol. 1992;129(2):145-153.

22. Rossier MF, Python CP, Capponi AM, Schlegel W, Kwan CY, Vallotton MB. Blocking T-type calcium channels with tetrandrine inhibits steroidogenesis in bovine adrenal glomerulosa cells. Endocrinology. 1993;132(3):1035-1043.

23. Payet MD, Durroux T, Bilodeau L, Guillon G, GalloPayet N. Characterization of $\mathrm{K}^{+}$and $\mathrm{Ca}^{2+}$ ionic currents in glomerulosa cells from human adrenal glands. Endocrinology. 1994;134(6):2589-2598.

24. Carbone E, Lux HD. A low voltage-activated, fully inactivating Ca channel in vertebrate sensory neurones. Nature. 1984;310(5977):501-502.

25. Carbone E, Lux HD. A low voltage-activated calcium conductance in embryonic chick sensory neurons. Biophys J. 1984;46(3):413-418.

26. Nowycky MC, Fox AP, Tsien RW. Three types of neuronal calcium channel with different calcium agonist sensitivity. Nature. 1985;316(6027):440-443.

27. Schrier AD, Wang H, Talley EM, Perez-Reyes E, Barrett PQ. $\alpha 1 \mathrm{H}$ T-type $\mathrm{Ca}^{2+}$ channel is the predominant subtype expressed in bovine and rat zona glomerulosa. Am J Physiol Cell Physiol. 2001;280(2):C265-C272.

28. Wolfe JT, Wang H, Perez-Reyes E, Barrett PQ. Stimulation of recombinant $\mathrm{Ca}(\mathrm{v}) 3.2$, T-type, $\mathrm{Ca}^{2+}$ channel currents by CaMKII $\gamma$ C. J Physiol. 2002; 538(pt 2):343-355.

29. Barrett PQ, Ertel EA, Smith MM, Nee JJ, Cohen CJ. Voltage-gated calcium currents have two opposing effects on the secretion of aldosterone. Am J Physiol. 1995;268(4 pt 1):C985-C992.

30. Rossier MF, Burnay MM, Vallotton MB, Capponi AM. Distinct functions of T- and L-type calcium channels during activation of bovine adrenal glomerulosa cells. Endocrinology. 1996;137(11):4817-4826.

31. Chen XL, Bayliss DA, Fern RJ, Barrett PQ. A role for T-type $\mathrm{Ca}^{2+}$ channels in the synergistic control of aldosterone production by ANG II and $\mathrm{K}^{+}$. Am J Physiol. 1999;276(5 pt 2):F674-F683.

32. Lotshaw DP. Characterization of angiotensin IIregulated $\mathrm{K}^{+}$conductance in rat adrenal glomerulosa cells. J Membr Biol. 1997;156(3):261-277.

33. Jackson AC, Yao GL, Bean BP. Mechanism of spontaneous firing in dorsomedial suprachiasmatic nucleus neurons. J Neurosci. 2004;24(37):7985-7998.
34. Puopolo M, Raviola E, Bean BP. Roles of subthreshold calcium current and sodium current in spontaneous firing of mouse midbrain dopamine neurons. J Neurosci. 2007;27(3):645-656.

35. Marcantoni A, et al. Loss of Cav1.3 channels reveals the critical role of L-type and BK channel coupling in pacemaking mouse adrenal chromaffin cells. J Neurosci. 2010;30(2):491-504.

36. Mangoni ME, et al. Functional role of L-type Cav1.3 $\mathrm{Ca}^{2+}$ channels in cardiac pacemaker activity. Proc Natl Acad Sci US A. 2003;100(9):5543-5548.

37. Hughes SW, Cope DW, Toth TI, Williams SR, Crunelli V. All thalamocortical neurones possess a T-type Ca2+ 'window' current that enables the expression of bistability-mediated activities. J Physiol. 1999;517(pt 3):805-815.

38. Huguenard JR, McCormick DA. Thalamic synchrony and dynamic regulation of global forebrain oscillations. Trends Neurosci. 2007;30(7):350-356.

39. Catterall WA, Goldin AL, Waxman SG. International Union of Pharmacology. XLVII. Nomenclature and structure-function relationships of voltage-gated sodium channels. Pharmacol Rev. 2005;57(4):397-409.

40. Koschak A, et al. alpha 1D (Cav1.3) subunits can form l-type $\mathrm{Ca}^{2+}$ channels activating at negative voltages. J Biol Chem. 2001;276(25):22100-22106.

41. Welling A, Ludwig A, Zimmer S, Klugbauer N, Flockerzi V, Hofmann F. Alternatively spliced IS6 segments of the alpha $1 \mathrm{C}$ gene determine the tissue-specific dihydropyridine sensitivity of cardiac and vascular smooth muscle L-type Ca2+ channels. Circ Res. 1997;81(4):526-532.

42. Lee JH, Gomora JC, Cribbs LL, Perez-Reyes E. Nickel block of three cloned T-type calcium channels: low concentrations selectively block alpha1H. Biophys J. 1999;77(6):3034-3042.

43. Crunelli V, Toth TI, Cope DW, Blethyn K, Hughes SW. The 'window' T-type calcium current in brain dynamics of different behavioural states. J Physiol. 2005;562(pt 1):121-129.

44. Hughes SW, Crunelli V. Thalamic mechanisms of EEG alpha rhythms and their pathological implications. Neuroscientist. 2005;11(4):357-372.

45. Welsby PJ, Wang H, Wolfe JT, Colbran RJ, Johnson ML, Barrett PQ. A mechanism for the direct regulation of T-type calcium channels by $\mathrm{Ca}^{2+} /$ calmodulin-dependent kinase II. J Neurosci. 2003;23(31):10116-10121.

46. Yao J, et al. Molecular basis for the modulation of native T-type $\mathrm{Ca}^{2+}$ channels in vivo by $\mathrm{Ca} 2+$ / calmodulin-dependent protein kinase II. J Clin Invest. 2006;116(9):2403-2412.

47. Chemin J, Traboulsie A, Lory P. Molecular pathways underlying the modulation of T-type calcium channels by neurotransmitters and hormones. Cell Calcium. 2006;40(2):121-134.

48. Iftinca MC, Zamponi GW. Regulation of neuronal T-type calcium channels. Trends Pharmacol Sci. 2009;30(1):32-40.

49. Funder JW, Blair-West JR, Coghlan JP, Denton DA, Scoggins BS, Wright RD. Effect of $\left(\mathrm{K}^{+}\right)$on the secretion of aldosterone. Endocrinology. 1969;85(2):381-384. 